\title{
SELECTED METHODOLOGICAL ASPECTS OF MULTIDIMENSIONAL ANALYSES OF REGIONAL SPACE
}

\author{
RAFAŁ KLÓSKA \\ University of Szczecin, Faculty of Management and Economics of Services, POLAND \\ e-mail: rafal.kloska@wzieu.pl
}

RECEIVED
ACCEPTED
JEL
CLASSIFICATION

KEYWORDS

ABSTRACT
10 December 2018

28 December 2018

C19, 018, R59

spatial economy, methodology, statistical analysis

The substantial research potential of already existing procedures, their development and proposing of new alternatives, as well as practical usability of taxonomic methods result in practically infinite possibilities in terms of their application in multidimensional analyses of regional space. They may play a significant part in the description, assessment and forecasting of development of individual regions. Having the knowledge, skills and competences, nowadays researchers are able to take advantage of guidance available in literature of the subject and the improving computer software. Nevertheless, due to lack of versatile solutions, every study has to be approached individually, making well thought-out decisions, often arbitrarily. The aim of this paper is to systematize certain methodological dilemma with regard to multidimensional analyses of regional space. The scientific discussion conducted makes it possible to answer questions of who and what is the subject of research of this type and to determine the characteristics of the most frequently undertaken research tasks.

\section{Introduction}

Most categories in economy are characterized by spatial diversification, and to make the right socio-economic decisions, it is necessary to get familiar with this phenomenon. Quantitative methods turn out to be of great assistance in this regard. They are widely used in empirical research today, including regional research projects, and their usability is unquestionable. They are widely used in socio-economic analyses and diagnoses, making the 
description and assessment of the way that variables tend to change in time and space substantially more accurate. Therefore, apart from theoretical considerations, which are of great importance, it is recommendable to master the skill of effective use of statistical tools and techniques, which broaden the scope of scientific speculations, allowing for a complex and objective analysis of economic phenomena. These may be simple, describable using a single variable, or complex, requiring at least two - and usually more - variables. The methodology of analysis of simple phenomena is well developed today; multi-dimensional analysis, which is much more complex, and thus more difficult and less developed, has nevertheless been subject to extensive research in the last several decades. The present study puts emphasis on methodological aspects of analyses of this type, associated with determination of the subject of research, quantification of the research field and the specific characteristics of the basic research tasks.

\section{Determination of the subject of research}

The basic unit in statistical research is an object. In multi-dimensional analyses of regional space, it is the region. The interdisciplinary nature of this concept, which has been studied by representatives of many research disciplines, and at the same time the differences stemming from characteristics of economy, regional economics and local government finances, as well as economic geography, spatial economy, sociology, ethnography and other fields lead to development of various approaches to the idea. Etymologically, the term comes from the Latin word regio, regionis, which can be translated as 'space', or, more precisely, a direction that delineates a certain area, and as a result of general acceptance for this definition, the word "region" is today used in many countries and languages. In economic literature, the term pertains to certain polarized socio-economic and political-administrative fragments of space, which in terms of their territory fall below the national, but above the local level (Cooke, Leydesdorff, 2006, p. 6). In the vocabulary of the European union, the space of member states has been divided, using the statistical criteria, into the so-called NUTS, distinguishing five individual levels. In Poland, NUTS 1 is equivalent to a macro region, NUTS 2 - to a province, NUTS 3 refers to subregions, NUTS 4 - to districts and cities with district rights, while NUTS 5 pertains to commune; at the same time, the former three levels are referred to as being regional, and the latter two - as being local. The basic regional level, which serves as a basis for the EU regional policy, is nevertheless the second degree domestic administrative unit (NUTS 2) (Korenik, 1999, p. 53; Strahl, 2005, p. 18; Paradysz, 2012, p. 191), which is why in Poland a region is most often perceived as equivalent to a province.

\section{Quantification of the research area}

Spatial economy, innovativeness of regions, socio-economic development, competitiveness of regions, regional development - these are just a few of terms that are common today, although they have not been clearly defined, but interpreted implicitly and understood intuitively. Multidimensional phenomena of this kind are complex characteristics, for which a far-reaching consensus with regard to their meaning is assumed. Due to lack of precision and ambiguity of meaning of such terms, despite many attempts made to define them precisely, in everyday practice they function as conventional expressions, lacking, however, any clearly specified measurement methods. The basic problem is selection of specific diagnostic characteristics that would allow for quantification of the research area. Abstractive concepts and general identifiers of the described multidimensional categories require specification that would consist first of identification and then of use of a carefully selected set of measures, and there are no widely accepted, universal solutions in this regard. The complex nature of socio-economic phenomena that emerge in 
regional space requires application of various measures, which should reflect all of the key characteristics of the phenomenon being analysed; an additional problem here is posed by difficulties due to lack or limited availability of specific statistical data. There is a generally acceptable notion of the information potential in this regard, which undoubtedly limits the complex description and assessment of regional space. Appropriate measurement requires a careful selection of the set of specific indicators, which should take into account the spatial and temporal scope, as well as the objective of analyses or diagnoses undertaken, and this issue has not been solved unambiguously so far; in empirical research on the subject, the sets of measures applied constitute a compromise between substantive premises and information capabilities and usually result from an arbitrary approach of the research team (Strahl, 2006, pp. 26-32). In other words, a long tradition of compromise between using the already gathered and available statistical data and indicators, which would be perfect for achievement of objective of a specific research project leads to a situation, in which in sets of identifiers for benchmark analyses, the sets of measures are selected according to the principle of the "best possible" choice (Graversen, Siune, 2008, p. 3). S. Wydmus has also underlined that in research of this type, we deal with a number of simplifications and generalizations, which stem from far-reaching synthesis of the multidimensional issues, mostly in the territorial dimension, as application of the same list of diagnostic characteristics applicable to different fields means that we assume that every country or region analysed is characterized by the same specific nature of development or strategy of decisions made despite the differences in their conditions (Wydmus, 1984, pp. 38-39). One should therefore understand that the final results of multidimensional benchmark analyses are determined mainly - apart from the statistical methods discussed further - by the list of variables to be applied in the research project. In many empirical research projects dedicated to the issue, the set of diagnostic variables is limited to a short analysis of characteristics based on substantive premises, or the mode of selection of these characteristics is left without much debate. Apart from substantive analysis of these characteristics, it seems reasonable at least to take into account the postulate of discrimination of features by applying the variability coefficient to elimination of quasi-constant variables. As the subsequent step, it is possible to apply a specific algorithm of formal procedures for formal and statistical selection with regard to the choice of variables proposed. Methods and techniques used at this stage have been widely described in literature, including such recommendable positions in this regard as the works of Z. Hellwig (1981), K. Jajuga (1993), M. Walesiak and E. Gatnar (2004), W. Pluta (1986), T. Grabiński, S. Wydmus and A. Zelias (1982, 1989), E. Nowak (1984, 1990), J. Pociecha, B. Podolec, A. Sokołowski and K. Zając (1988), as well as A. Malina (2004). One has to realize, however, that there is no simple answer to the question whether in selection of the final variables we should apply the criterion of variability or correlation, or perhaps introduce diversified weights, expressing the relative importance of variables, or apply other procedures, allowing, for instance, for grouping of characteristics or selection of their representatives. Potential weighing of features constitutes a separate problem and yet another methodological dilemma. In literature, there have been certain proposals in this regard (Grabiński, 1992, pp. 34-35), and it is also possible to seek expert opinions. Nevertheless, the issue has not been clearly resolved and no generally acceptable procedure has been developed. Therefore, in practice, most researchers attach the same importance to each feature, applying equal weights (Sokołowski, 1985, p. 48).

It should therefore be underlined that every case has to be assessed individually. Using various techniques and tools for selection of the initial variables, we may obtain different sets of characteristics of the objects being analysed. This is why strictly substantive selection is so important in searching for the ultimate list of diagnostic variables. In-depth recognition of the phenomenon being analysed, as well as familiarity with the achievements 
made so far, own reflections and expert opinions, common sense or even experience in research of this type, combined with intuition, are of utmost importance.

\section{The specific nature of basic research tasks}

As the aim of regional research is usually description and assessment of sets of object, the main two research tasks, presented in many research papers, are assumed to consist of grouping and linear ordering. The former allows for placing the statistical data in order, and it is limited to dividing the set of objects into groups of units that are similar in terms of the features applied to describe the phenomenon being examined. The second research task - linear ordering - can be brought down to putting the objects being analysed in order according to a specific criterion, which makes it possible to assign them a certain hierarchy. For the purpose of valuation of the objects being compared, an appropriate synthetic measure is applied (Zeliaś, 1991, p. 76; Czyżycki, 2018, p. 207). The substantial research potential of the already developed procedures, their development or proposing new ones creates practically unlimited possibilities of applications, particularly in regional research. In a classical taxonomic approach, multidimensional observations of the diagnostic variables applied in the objects examined allow for spatial analysis from a static (cross-cutting) perspective. Introduction of the additional dimension of time in dynamic research, that is, on the basis of multidimensional observations coming from various points or periods in time allows us to examine a complex issue of this kind from the perspective of the so-called data cube. This has been indicated, among others, by K. Jajuga (1987, pp. 14-16), M. Walesiak (1993, pp. 30-31) and J. Hozer (1987, p. 14). In terms of geometry, this figure can be imagined as a cross-sectional/temporal multidimensional series in a three-dimensional coordinate system, in which individual axes present dimensions of objects, variables and time units, respectively. Space created by sets of:

- objects $Y=\left\{y_{1}, y_{2}, \ldots, y_{n}\right)$,

- characteristics $X=\left\{x_{1}, x_{2}, \ldots, x_{k}\right)$,

- time units (moments or periods) $T=\left\{t_{1}, t_{2}, \ldots, t_{N}\right.$ ),

and their multi-aspect analysis, enabled by the data cube, results in an enormous field of applicability of the multidimensional statistical analysis methods. Taxonomic issues can then be of simple nature (including the already mentioned classical issue of taxonomy, or grouping of multi-characteristics objects in a time unit), complex (combining two simple problems, allowing for analysis of e.g. time-objects or time-characteristics) or complex (encompassing a total examination of objects, characteristics and time units, taking into account the so-called time-characteristic-objects) (Sokołowski, 1982, pp. 65-71). Thus, a three-dimensional data cube can be used for an examination of:

a) an overall approach - encompassing the entire data cube for $n$ objects described using $k$ variables in $T$ time units;

b) partial approaches - from the perspective of: object-variable, where $n$ objects are considered from the perspective of $k$ variables in a single given time unit; from the perspective of: time-variable, where the study is focused on a single object with regard to $k$ variables over $T$ time units; from the perspective of: objecttime, where $n$ objects are described in $T$ periods from the perspective of a single specific variable (this is an issue of single-dimensional analysis, not applicable to complex phenomena).

Nevertheless, it is necessary to realize that there is no single answer to the question, which procedure is right for a specific empirical research project. Therefore, to be able to use specific taxonomic methods to group and 
place in order a linear set of objects, the researcher must have the appropriate knowledge and skill sin this regard. In classification and linear hierarchy of sets of objects, despite numerous methodological guidelines in specialist literature, which has grown very rich, at least some of the decision-making problems have not been clearly solved and require a well thought out, responsible decision, made arbitrarily by the research leader.

\section{Conclusions}

The multitude of theoretical research papers, as well as empirical works, indicates clearly the practical usability of multidimensional analyses of regional space. As a result of application of computer software, which is available nowadays, it is relatively easy to use the appropriate statistical method, provided that the researcher is methodically and substantively familiar with the phenomenon being described. A conscious researcher must make well-thought-out decisions and know the level of significance of results obtained when using specific tools. In this article, by pointing out to the selected methodological aspects, the authors have put in order and partially solved the emerging dilemmas with regard to definition of the object of research, quantification of the research area and the specific nature of the research tasks undertaken. While certain problems have been explained, others have been merely indicated and they may serve as a starting point for scientific debate. Undoubtedly, research in this area should be continued.

\section{References}

Cooke, P., Leydesdorff, L. (2006). Regional Development in the Knowledge-Based Economy: The Construction of Advantage. The Journal of Technology Transfer, 31 (1), 5-15.

Czyżycki, R. (2018). Non-model methods in the study of regional development - the impact of the aggregation formula on the obtained research results. Proceeding of the 2018 VII International Scientific Conference Determinants of Regional Development, 1, Piła, 12-13 April. Retrieved from: http://web.pwsz.pila.pl/ pes/index.php/proceedings/article/view/165/131.

Grabiński, T. (1992). Metody taksonometrii. Kraków: Wydawnictwo Akademii Ekonomicznej w Krakowie.

Grabiński, T., Wydmus, S., Zeliaś, A. (1982). Metody doboru zmiennych w modelach ekonometrycznych. Warszawa: PWN.

Grabiński, T., Wydmus, S., Zeliaś, A. (red.). (1989). Metody taksonomii numerycznej w modelowaniu zjawisk społeczno-gospodarczych. Warszawa: PWN.

Graversen, E., Siune, K. (2008). Statistical Indicators for R\&D and Innovation - A guide for Interpretation and Valuation. Aarhus: The Danish Centre for Studies in Research and Research Policy. Retrieved from: http://www.cfa.au.dk/fileadmin/site_files/ filer_forskningsanalyse/dokumenter/Diverse/D10.pdf.

Hellwig, Z. (1981). Wielowymiarowa analiza porównawcza i jej zastosowanie w badaniach wielocechowych obiektów gospodarczych. In: W. Welfe (ed.), Metody i modele ekonomiczno-matematyczne w doskonaleniu zarządzania gospodarką socjalistyczną. Warszawa: PWE.

Hozer, J. (1987). Struktura podmiotowa i rzeczowa a dynamika systemów gospodarczych. Wiadomości Statystyczne, 2, 13-15.

Jajuga, K. (1987). Statystyka ekonomicznych zjawisk złożonych - wykrywanie i analiza niejednorodnych rozkładów wielowymiarowych. Wrocław: Wydawnictwo Akademii Ekonomicznej we Wrocławiu.

Jajuga, K. (1993). Statystyczna analiza wielowymiarowa. Warszawa: Wydawnictwo Naukowe PWN.

Korenik, S. (1999). Wybrane teorie rozwoju regionu ekonomicznego. Prace Naukowe Akademii Ekonomicznej we Wrocławiu, 799, 51-62.

Malina, A. (2004) Wielowymiarowa analiza przestrzennego zróżnicowania struktury gospodarki Polski według województw. Kraków: Wydawnictwo Akademii Ekonomicznej w Krakowie.

Nowak, E. (1984). Problemy doboru zmiennych do modelu ekonometrycznego. Warszawa: PWN.

Nowak, E. (1990). Metody taksonomiczne w klasyfikacji obiektów społeczno-gospodarczych. Warszawa: PWE.

Paradysz, J. (2012). Statystyka regionalna: stan, problemy i kierunki rozwoju. Przegląd Statystyczny, 2 (numer specjalny), 191-204. 
Pluta, W. (1986). Wielowymiarowa analiza porównawcza w modelowaniu ekonometrycznym. Warszawa: PWN.

Pociecha, J., Podolec, B., Sokołowski, A., Zając, K. (1988). Metody taksonomiczne w badaniach społeczno-gospodarczych. Warszawa: PWN.

Sokołowski, A. (1982). O zagadnieniach taksonomicznych. Zeszyty Naukowe Akademii Ekonomicznej w Krakowie, 165, 65-71.

Sokołowski, A. (1985). Wybrane zagadnienia pomiaru i ważenia cech w taksonomii, Zeszyty Naukowe Akademii Ekonomicznej w Krakowie, 203, p. 41-53.

Strahl, D. (2005). Zróżnicowanie rozwoju regionalnego na poziomie NUTS-2 w krajach Unii Europejskiej, Prace Naukowe Akademii Ekonomicznej we Wrocławiu, 1083, 17-26.

Strahl, D. (ed.) (2006). Metody oceny rozwoju regionalnego. Wrocław: Wydawnictwo Akademii Ekonomicznej im. Oskara Langego we Wrocławiu.

Walesiak, M. (1993). Statystyczna analiza wielowymiarowa w badaniach marketingowych. Wrocław: Wydawnictwo Akademii Ekonomicznej we Wrocławiu.

Walesiak, M., Gatnar, E. (eds.) (2004). Metody statystycznej analizy wielowymiarowej w badaniach marketingowych. Wrocław: Wydawnictwo Akademii Ekonomicznej im. Oskara Langego we Wrocławiu.

Wydmus, S. (1984). Wykorzystanie procedur porządkowania liniowego w predyktywnej analizie stopnia dysproporcji rozwojowych w gospodarce światowej. Zeszyty Naukowe Akademii Ekonomicznej w Krakowie 181, 37-61.

Zeliaś, A. (ed.) (1991). Ekonometria przestrzenna. Warszawa: PWE.

Cite this article aS: Klóska, R. (2018). Selected methodological aspects of multidimensional analyses of regional space. European Journal of Service Management, 4 (28/2), 201-206. DOI: 10.18276/ejsm.2018.28/2-25. 